\title{
Taking out the Trash
}

\section{On Excavating Settlements in General, and Houses of the Battle Axe Culture in Particular}

\author{
Åsa M Larsson
}

\begin{abstract}
Archaeological interpretation rests partly on theory and partly on material remains, and changes in field methods can cause major changes in both areas. Longhouses were virtually unknown on mainland Sweden until the introduction of the excavator machine in the late 1970s. However, this method is biased in that the cultural practice of some periods is favoured at the expense of others. From the Battle Axe culture very few houses and artefacts have been found, and it has been suggested the sites were not true settlements. This view is challenged by showing that taphonomic processes and cultural practice combine to make this period difficult to identify using the standard field method. Paradoxically, some other periods have no more remains and/or house structures than the Battle Axe period has, but they are not subjected to the same debate. Comparison with Corded Ware sites in Europe provides support for the argument that the scarcity of Battle Axe settlements is mainly due to taphonomic processes. The article calls for more reflective field methods on all prehistoric settlements.
\end{abstract}

Asa M. Larsson. Department of Archaeology and Ancient History: Uppsala University, Bor 626, SE-751 26 Uppsala, Sweden

Key words: Neolithic, Bronze Age, Iron Age, TRB, Battle Axe culture, Corded Ware culture, Late Neolithic, settlement, house, spatial organisation, taphonomy, field method, pottery

In this article I will discuss the apparent problem with finding and identifying settlements belonging to the Battle Axe culture (c. 2850-2350 BC). These difficulties have led some researchers to speculate that the Battle Axe culture (BAC) was only a ritual custom within a larger Neolithic society (e.g., Carlsson 1998: 63f; Gill 2003: 182, 184, 192; Nordqvist 1997: 164ff). However, in order to challenge this view it is necessary to widen the discussion to include settlements from other periods of Swedish prehistory. I hope to show that the apparent absence of BAC settlements is partly due to the differential treatment archaeologists give to remains from different periods, and partly due to taphonomic processes not yet fully explored. Some important questions will be raised: What criteria do we use when we interpret a site as a settlement, and are they based on arbitrary models of human behaviour? Are our methods of excavation always optimal for all kinds of remains, or are some structures and periods at a serious disadvantage? 
If so, can we adjust these methods in a way that may uncover new aspects of prehistoric sites? And perhaps most important: are there really no settlements of the Battle Axe culture?

\section{PREHISTORIC HOUSES - A NOVELTY ITEM}

"Up until the mid 1980s, prehistoric houses with a visible and clear structure were a virtually unknown occurrence in archaeological excavations." (Streiffert 2005:39, my transl.)

In archaeological excavations of the $21^{\text {st }}$ century houses are a regular occurrence, and in our textbooks the settlements of the Neolithic, Bronze Age, and Iron Age are illustrated by increasingly large and imposing longhouses, alone or in a group. It is easy, then, to forget that until the beginning of the 1980 s very few houses had been found at prehistoric sites in Sweden (Göthberg 1995; Göthberg et al. 1995; Säfvestad 1995). The only exceptions were a few houses on Gotland, Öland and in Norrland, which had preserved wall embankments, and a few notable publications where construction details could be presented (e.g., Beskow-Sjöberg 1977; Hyenstrand 1973; Stjernquist 1969). At the most a few huts and pit-houses were identified, or houses with poorly preserved construction details (Säfvestad 1995:13ff). There are also a few examples of houses excavated in the 1970s, which were not published until the ' 80 s (e.g., Bennett 1985).

This had major consequences for the interpretation of prehistoric social structures. For instance, in Scania pit-houses were practically the only formally recognized house type of the Iron Age, which led to most settlements being interpreted as seasonal market places (Säfvestad 1995:15). Archaeologists also interpreted the Bronze Age society as consisting of largely mobile herders and pastoralists with no permanent settlement, whose sites were identified by heaps of fire-cracked stones. As late as 1984, Bronze Age settlements in Central Sweden were described as approximately $50 \mathrm{~m}^{2}$ in size and containing little more than these heaps of fire-cracked stones (Petré 1984). Just two years later the excavations started at Apalle in Uppland which were to result in altogether 45 houses - small and large - from the Bronze Age (Ullén 2003). But by then the major shift in excavation method and focus had already transformed the settlement archaeology in Scania.

Archaeologists in Scania had postulated that there should have been longhouses built in the Bronze and Iron Ages, based on finds made in Denmark where the excavator machine, which could strip large surfaces for a better overview of the features, had been introduced (Stjernquist 1969; Widholm 1984). However, in Scania these houses were still almost completely absent, and second-hand evidence had to be used to infer house building - such as large clay pits that were interpreted as having been dug to extract daub for walls (Widholm 1984:85). In 1979 large rescue excavations were initiated at Köpinge and Fosie IV, and for the first time the excavator machines were put to use on a grand scale in Sweden. The 
result would be a virtual explosion of house structures. Longhouses from the Neolithic to the late Iron Age, from 13 to $60 \mathrm{~m}$ in size, were discovered and identified, but apart from a few articles in the early 1980 s the main publications of the material did not appear until 1989 (the Late Neolithic) and 1993 (the Bronze and Iron Ages) (Björhem \& Säfvestad 1989, 1993; Tesch 1993).

In the decade following Fosie and Köpinge, continued excavations at, for instance, Ullevi (Linköping) in Östergötland and Apalle in Uppland would irrevocably alter the way archaeologists perceived prehistoric society and settlement (Karlenby 1994; Ullén 2003). The change was so extensive that today it is almost forgotten how very different the situation was only a couple of decades ago. That a change in field method could alter our understanding of prehistoric society in such a profound way is a valuable lesson, and we must not fall into a trap of complacency in the belief that we have now solved all problems associated with excavations. The use of excavator machines is excellent - indispensable even - when it comes to identifying large structures and patterns of features. However, if it is not combined with hand-dug excavation of the topsoil very little of the artefacts and material remains will be rescued. How little will be discussed below.

\section{A HOUSE OF THE BATTLE AXE CULTURE}

It is indeed a fact that very few house structures have been convincingly interpreted as belonging to the BAC, but as I will argue below this lack of houses is not a problem solely for the Middle Neolithic B. For now I will present one of the more convincing BAC houses. In 1993, a planned railway construction at Fågelbacken, Hubbo Parish, Västmanland led to an extensive rescue excavation. The area had consisted of cultivated fields up until recently, and pits dug in plough soil yielded Battle Axe pottery in a restricted area. Since this is such a rare find, the archaeologists decided to expand the hand-dug trench at this spot. In total, $160 \mathrm{~m}^{2}$ were dug by hand in a $1 \mathrm{~m}$ grid. The finds could then be compared to the postholes found when the whole area was later stripped by machine. A two-aisled house approximately $13 \times 4 \mathrm{~m}$ was identified (fig. 1). The finds were clearly confined within the house structure, to such an extent that in some of the excavated squares the pottery was present in one half and virtually absent in the other (Hallgren 2000).

In total, $1.5 \mathrm{~kg}$ of Battle Axe pottery, $425 \mathrm{~g}$ of knapped quartz and flint, and $60 \mathrm{~g}$ of burned bones were found, as well as two fragments of a flint axe, a scraper and a couple of other tools (Hallgren 2000, unpubl.). This may not seem like a lot, and indeed one often encounters arguments against this being a regular settlement on account of the small quantity. It is therefore interesting to compare the Fågelbacken house with the Late Neolithic houses found at Fosie IV. In their publication of houses dated to the Late Neolithic and Early Bronze Age at Fosie, Björhem and Säfvestad present a very clear overview of the structures, features, finds and ${ }^{14} \mathrm{C}$-dates. The quantity of finds varies among the houses, but it is clear 


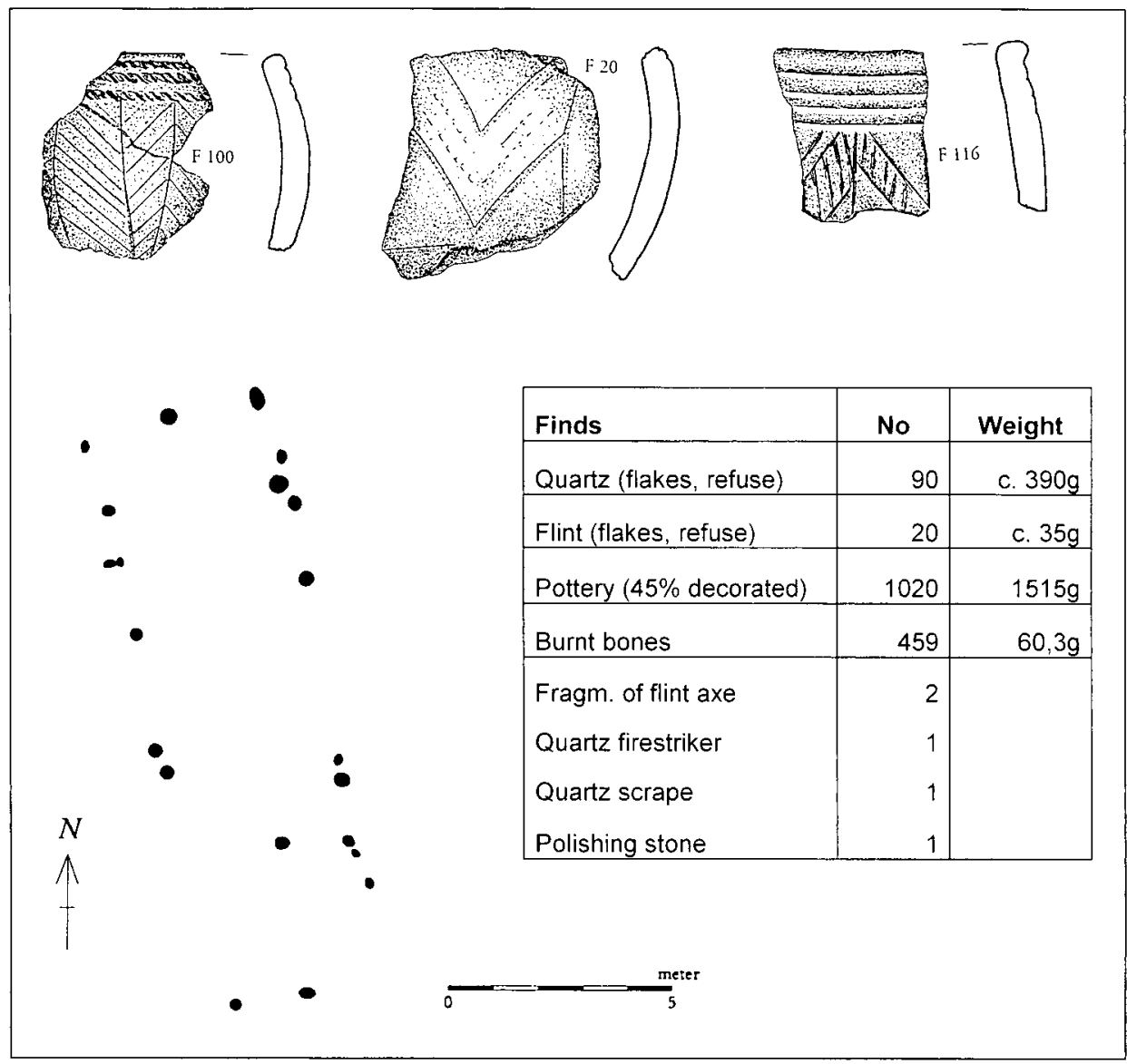

Fig. 1. Battle Axe house from Fägelbacken. Hubbo Parish, Västmanland. The central area of the house, where one might expect to find roof-bearing posts, was partially disturbed by Iron Age hearths. The table lists artefacts found in connection to the house. Three examples of the pottery are also shown. (After Hallgren 2000)

that very few contain more than Fågelbacken and most contain far less (fig. 2). In general less than $200 \mathrm{~g}$ of pottery, sometimes less than $100 \mathrm{~g}$, have been found in the houses, and almost all the sherds are undecorated and nondescript in appearance. Knapped flint varies from less than $100 \mathrm{~g}$ to $2 \mathrm{~kg}$. As for osteological material, it is virtually absent, and neither is there any quantity of daub to speak of. A few tools of mainly general Neolithic-Bronze Age manufacture make up the rest of the finds (Björhem \& Säfvestad 1989).

A couple of houses (nos. 11 and 92) have somewhat larger quantities of finds, though only house 92 has any quantity of pottery to speak of (approx. $4.3 \mathrm{~kg}$ ). What sets these two houses apart is that they had pits dug inside the house where the majority of the material remains were found (Björhem \& Säfvestad 1989:32ff, $52 \mathrm{ff}$ ). More than $90 \%$ of the Late Neolithic material from Fosie consists of stone 


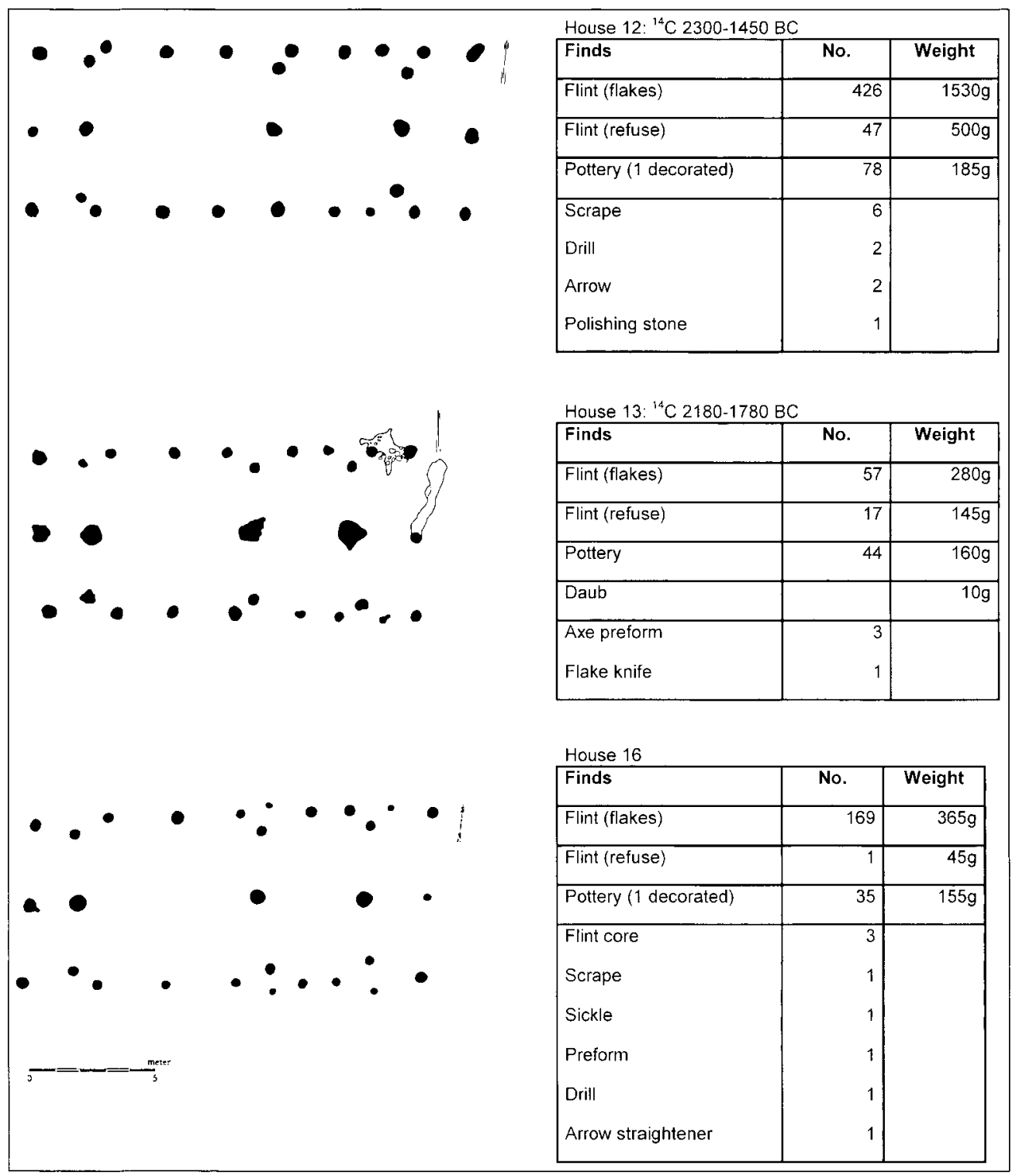

Fig. 2. Three of the Late Neolithic houses excavated at Fosie IV, Malmö, Scania. The tables list the artefacts found in connection to the respective houses. Houses 12 and 13 were ${ }^{1+} \mathrm{C}$-dated by charcoal found in postholes. (Afier Björhem \& Säfiestad 1989)

tools and refuse from flint knapping. The pottery is scarce and undecorated. Fosie was mainly excavated by machine, and only visible features and dark cultural layers were dug by hand, which of course means that a comparison with Fågelbacken is not completely justified. However, most of the finds from Fågelbacken came from below the plough layer in what will be shown to be a sunken part of the house. The most important point, however, is that no archaeologist has ever 
questioned whether the Fosie buildings were used as living quarters - despite the meagre remains of everyday life.

\section{TRACES OF PAST LIVES}

The finds from many of the Bronze and Iron Age houses are no more impressive, and this is a pattern that emerges at many settlement sites of the Bronze and Iron Ages excavated in the last decades.

"[T] they were very thin and had few finds. Only a few traces of settlement were found." (Tesch 1993:83)

A quick perusal of reports from even some of the more well-known sites makes clear the fact that if any quantities of finds are collected, they do not come from the houses but from hearths and refuse pits. The Bronze Age settlement of Vistad, Östergötland, where three small houses and part of two more were found in an area of $1950 \mathrm{~m}^{2}$, had a total amount of 186 datable sherds of pottery weighing no more than $2.3 \mathrm{~kg}$ (Larsson 1993:56). Whether Vistad should be interpreted as a settlement or a ritual area has been debated, but this is due to the unique house structure and the presence of a palisade, not to the scarcity of pottery.

At the large excavated site of Vrå/Knivsta in eastern Central Sweden, with remains from the Middle Neolithic to the Early Iron Age, almost all the pottery was found in patches of darker cultural layers, hearths and heaps of fire-cracked stones. An abundance of postholes were found, many of which belonged to identifiable houses. However, in these features only $0.2 \%$ of the pottery was found - some $100 \mathrm{~g}$ (Eriksson 1997:124). It is a telling point that $42.000 \mathrm{~m}^{2}$ with at least 19 houses, and settlements ranging from the Late Neolithic to the Roman Iron Age, yielded no more than $51 \mathrm{~kg}$ of pottery. Even more striking is when one considers that over half of the pottery came from a small part of the site, and dates mainly to the Late Bronze Age. This is a general rule that archaeologists have remarked upon: the Late Bronze Age settlements usually yield far more material remains than both the Early Bronze Age and the Iron Age (Aspeborg 1997; Larsson 1997: 22f).

We cannot stipulate an arbitrary quantity of pottery that must be found in order to interpret a site as a settlement. The presence of various materials is heavily dependent on cultural factors of production, use and depositing that change over time, as well as taphonomic processes and excavation methods.

It is only logical that extremely little of the material remains of a settlement should end up in postholes and be preserved until modern times. If we remove the upper layer of soil that contains the remains strewn about the habitation site without even examining it, we depend completely on whether the people who lived at this locality dug deep pits and deposited large quantities of artefacts. And preferably these would be artefacts that could stand a chance of surviving thousands of years of taphonomic processes, such as stone and pottery, rather 
than wicker baskets, leather, textiles, and tools of wood and bone. This seems to have been a practice at Late Bronze Age settlements (Borna-Ahlkvist et al. 1998; Jaanusson 1981; Ullén 2003). However, even here the pottery is not evenly distributed in the features, or over the whole area. Of the $128 \mathrm{~kg}$ of pottery retrieved at Pryssgården, almost $60 \%$ came from pits and 20\% from hearths and cooking pits; only $5 \%$ came from the postholes. The figures make it plain that the pottery was strongly tied to the areas with cooking pits, whereas areas with houses but no cooking pits were practically empty of pottery remains (Borna-Ahlkvist, Lindgren-Hertz, \& Stålbom 1998: figs. 85, 88).

Depositing material in this fashion is not a universal human trait; rather, it is a cultural one - and the evidence from other periods' settlements makes this clear (Aspeborg 1997; Larsson 1997). Personally I cannot think of a reason for any society to feel compelled by nature to dig deep pits and deposit pots and stone tools in them, rather than storing the objects in an attic, on raised platforms, or in wooden chests, to name a few alternatives. Nor is pottery the preferred form of storage in every culture that practices the craft - there are several viable options. We must be careful not to elevate cultural practice to universal models of behaviour. Rather, the varying forms of spatial organisation that become apparent when we study settlements from different periods constitute a very revealing window to past social structure. While I believe all archaeologists would agree on this in theory, the excavation methods that are often standard today seem to depend to a very large degree on the premise that prehistoric people should dig pits and deposit non-organic materials in them. This means that some periods are given an advantage, and others are being continually disadvantaged.

\section{SUNKEN-FLOOR HOUSES}

As I mentioned above, the material retrieved from the house at Fågelbacken was not evenly distributed within the structure. As can be seen from the distribution of pottery and burned bones, they are obviously concentrated to the southern

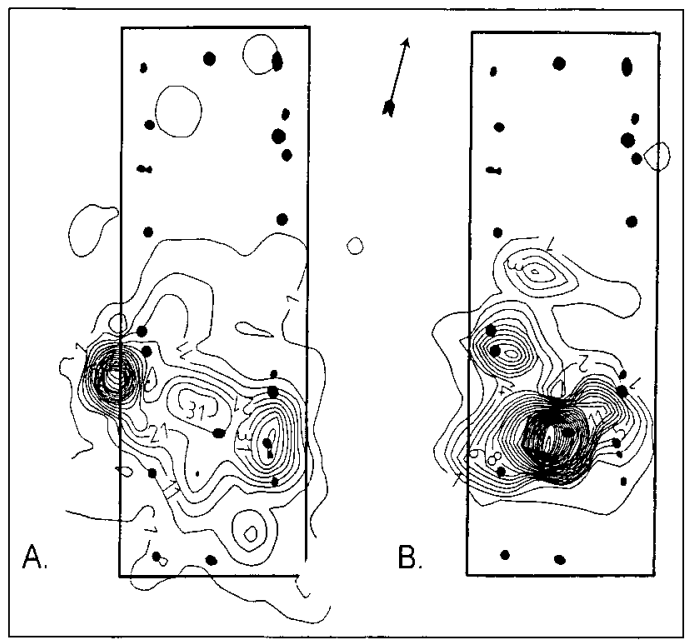
part of the house (fig. 3). If one compares the distribution of all the knapped quartz to that found beneath the plough layer, it is clear that this is also concentrated to the southern half (fig. 4). As well as a

Fig. 3. The Battle Axe house at Fagelbacken with the distribution of different finds showing: A: Pottery; B: Burnt bones. An area of $160 \mathrm{~m}^{2}$ was hand dug in a $1 \mathrm{~m}$ grid, extending beyond the house. The western concentration of pottery: is mostly due to a pottery deposit/1ubbish pit ${ }^{\circ}$ moutside the presumed wall. (After Hallgren 2000) 


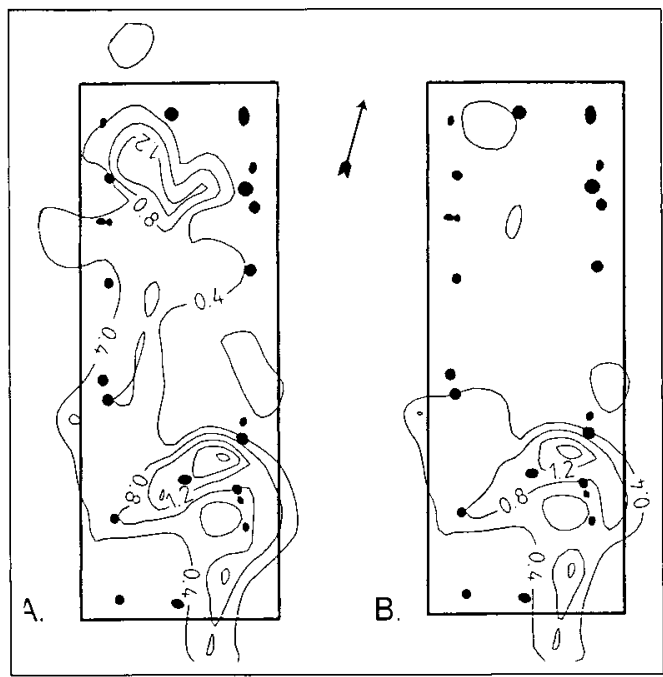

Fig. 4. The Battle Axe house at Fågelbackenthe distribution of knapped quartz. A: All the quartz retrieved in the hand-dug area: $B$ : The quartz found below the plough layer. The distribution of finds in figs. 3 and $3 b$ is a strong argument that the house had a sunken floor in the southern half, which helped preserve the artefacts from the ploughing. (After Hallgren 2000)

spatial organisation of the living space, the excavators interpreted this as evidence of a sunken floor in this part of the house, which led to the material remains being better preserved here (Hallgren 2000: 19ff).

This specific construction - a twoaisled house with a sunken floor in one half - occurs in contexts dated to both the Middle Neolithic B and the Late Neolithic. The first BAC house identified in Sweden, at Kabusa in Scania, probably had this construction: a dark trapezoid feature approximately $13.5 \times 5-7 \mathrm{~m}$ oriented SW-NE, with several postholes surrounding it (fig. 5). The edges of this shallow feature were at times difficult to ascertain in the sandy soil. It may be the partially destroyed remains of a sunken floor, or possibly the feature represents most of the original floor with a sunken part in the west (Larsson 1989).

Most of the material at the site was found in a few pits and features close to the house. The stone material consists of two thickbutted hollow-edged flint axes, several round scrapers, and a number of flakes from the last stages of the production of thick-butted axes. The pottery sherds were generally small, though a few rim sherds from larger vessels were also found. They were decorated with tooth stamp, whipped cord, nail impressions and lines, in patterns consistent with late Battle Axe pottery (such as types J,

Fig. 5. The house from Kabusa, St Köpinge Parish, Scania, ${ }^{14} \mathrm{C}$-dated to the second half of the Middle Neolithic B. The large feature marked by drawn lines was visible as a dark grey-brown colouration, with traces of soot and some charred stones. The feature was no more than $6 \mathrm{~cm}$ deep and there was notable erosion at the site. It might have been all that was left of a sunken floor: (After L. Laisson 1989: fig. 4)

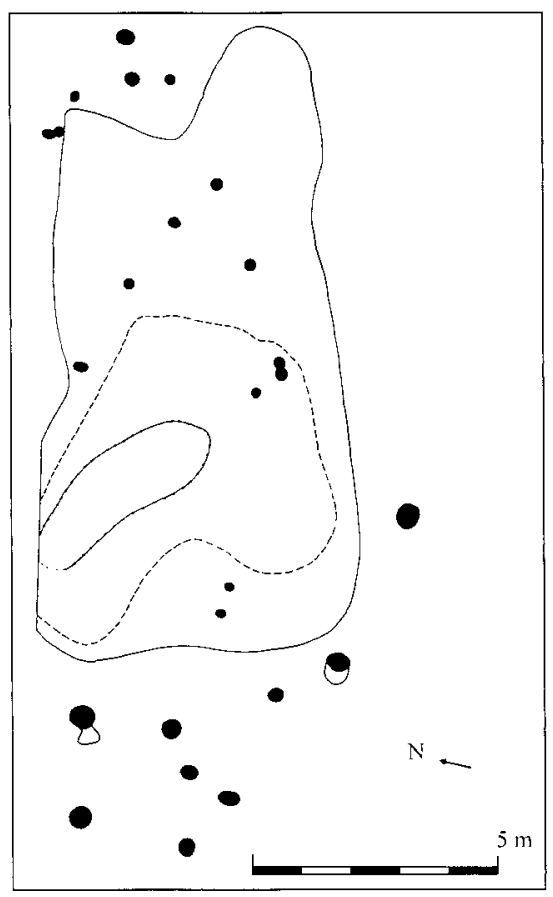


Fig. 6. Sunken-floor houses from northern Jutland, Denmark. The sunken floor is in the eastern part of the houses. A: House D at Myrhøj, Vesthimmerland. B: Bejsebakken, Aalborg Amt. Both are from settlements dated to the early Late Neolithic by ${ }^{1+} \mathrm{C}$-analysis andior artefacts. (After Artursson 2005:38)

$\mathrm{K}$ and $\mathrm{M}$ ). The vessel shapes are also consistent with BAC pottery. Three ${ }^{14} \mathrm{C}$-analyses made on hazelnuts and charcoal date the settlement to c. 2600-2300 BC (Larsson 1989).

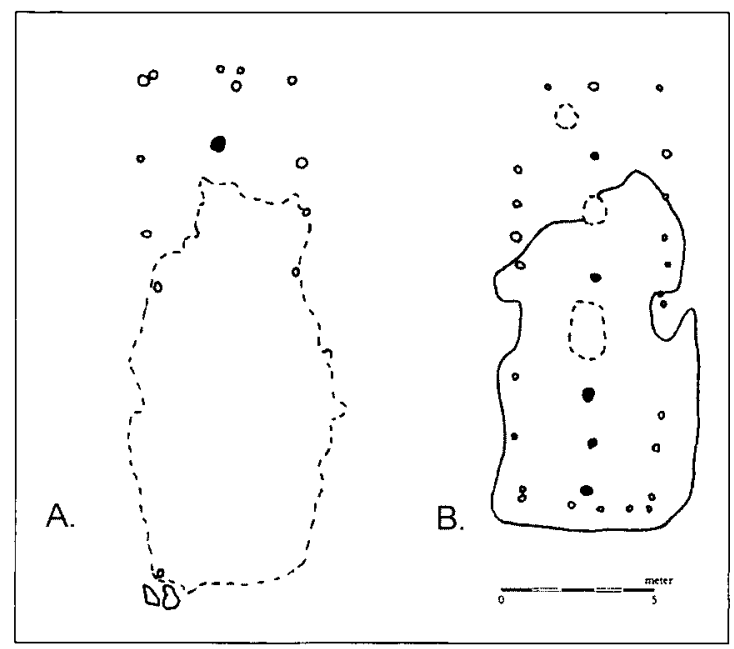

There have been several finds

of houses of this type in Jutland, for example at Myrhøj, Egehøj, Bejsebakken and Hemmed (Artursson 2005: 33ff). The ${ }^{14} \mathrm{C}$-dates and artefacts place them in the transition between the Middle Neolithic B and the Late Neolithic (fig. 6). Similar houses have also been found at Svågertorp (Scania) and possibly at Gröndal (Uppland). At Svågertorp 8A about $260 \mathrm{~g}$ of pottery were retrieved, mainly from the sunken part, and about $50 \mathrm{~g}$ of burned bones (fig. 7). The pottery was of a general type, but seven sherds were determined as Late Neolithic/Early Bronze Age. A ${ }^{14} \mathrm{C}$-dated wheat grain gave the result $2030-1780 \mathrm{BC}$ (Rosberg \& Lindhé 2001). At Gröndal several finds from the Late Neolithic/Early Bronze Age were recovered; and in the house with the sunken floor (house A) about $1.5 \mathrm{~kg}$ of pottery and about $3.5 \mathrm{~kg}$ of knapped stone, mainly quartz (fig. 8), were found. A hearth inside the house was dated to the LN/EBA (Hamilton \& Runeson 2003).

It seems clear that this type of house originated in the Middle Neolithic B and continued through the Late Neolithic. The important issue of settlement continuity will be discussed further on.

\section{A HOUSE IS A HOUSE IS A HOUSE...}

As has been stated, houses convincingly identified as belonging to the BAC are few, but this period is hardly alone with that problem. The abundance of Late Neolithic houses found in Scania often blinds us to the fact that north of this area they are extremely scarce. Apart from a few found at Linköping (Biwall et al. 1997), the house at Gröndal is quite unique. At Annelund, Uppland, house II was originally interpreted as a two-aisled $\mathrm{LN}$ house, but it was later reinterpreted as a three-aisled house (Hamilton \& Runeson 2003:135). In addition, the ${ }^{14} \mathrm{C}$-dates from material found at this house range from the Late Neolithic to the Early Iron Age, which highlights the difficulties in dating charcoal and cereal grains from sites with settlements from many different periods (Biwall et al. 1997:289). 


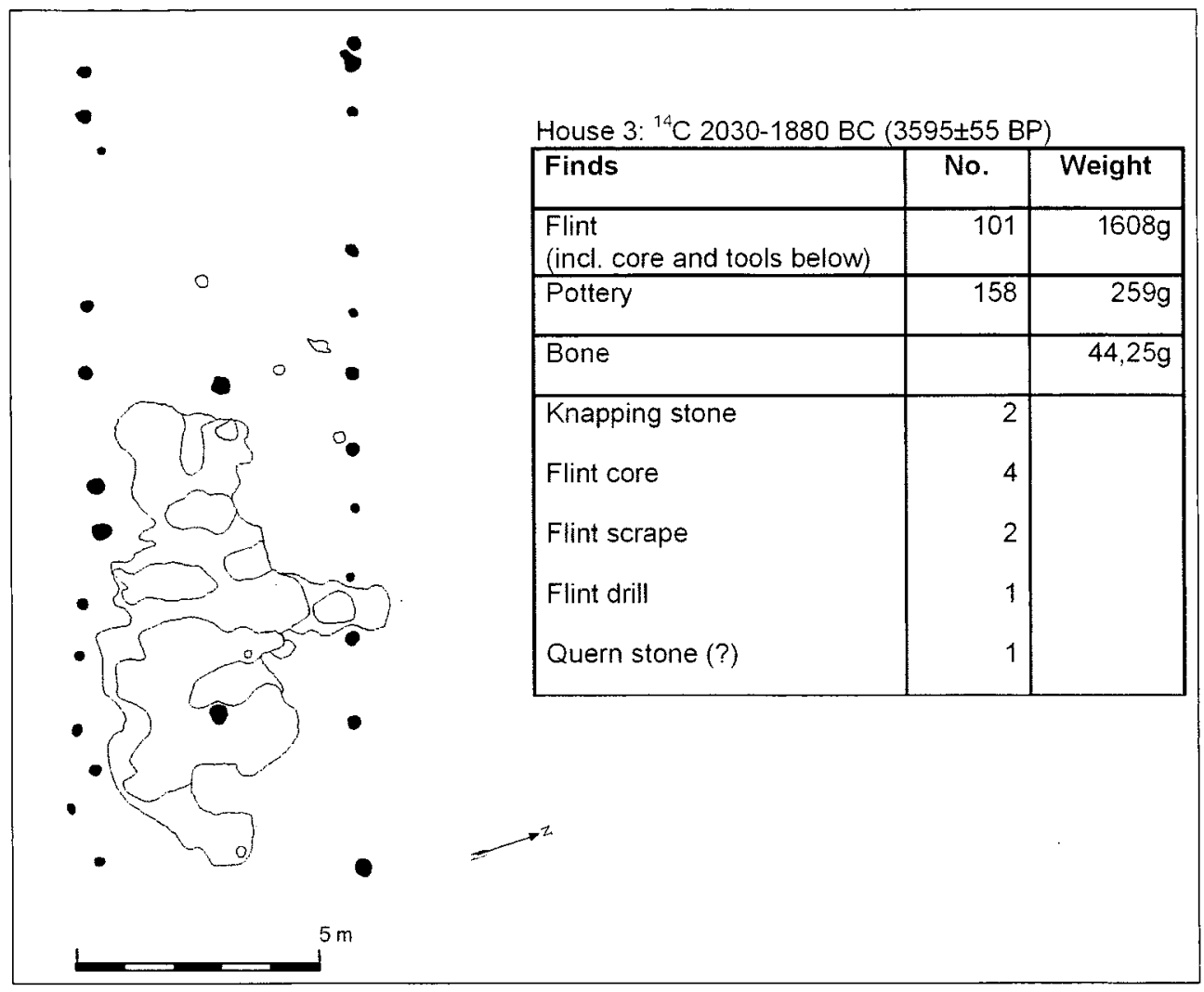

Fig. 7. Late Neolithic house found at Svaggertorp 8A, Malmö, Scania. The feature in the eastern half of the house consisted of grey-brown sandy clay with a depth of $5-22 \mathrm{~cm}$. It contained burnt and unburnt flint, pottery, and a few other artefacts listed in the table. Almost all finds in the house came from the coloured feature, which was hand dug and interpreted as a sunken floor: (After Rosberg \& Lindhé 2001: fig. 10)

Indeed, this is a constant problem with most two-aisled houses, since typologically speaking they may derive from at least the Early Neolithic to the Early Bronze Age - a period of 2500 years. In some cases construction details may narrow down the period, but in most cases the houses are simply of too general a construction or too poorly preserved. In those instances we have to rely on ${ }^{14} \mathrm{C}$ dates and the material remains found inside or close to the house.

It presents a major problem when we find such a house but not enough artefacts to make a credible inference about the period. At Vrå/Knivsta, pottery from both the BAC and the Late Neolithic was found (Eriksson 1997). A pair of two-aisled houses were also identified, one with a clay floor in the northern part (Göthberg et al. 1997:62, 65) (fig. 9). However, no finds of any consequence were made inside the houses, nor were they dated. It is probable that they were constructed during the Neolithic, though whether one, or both, or none of the houses can be associated with the BAC pottery or the LN pottery at the site, is impossible to ascertain. 


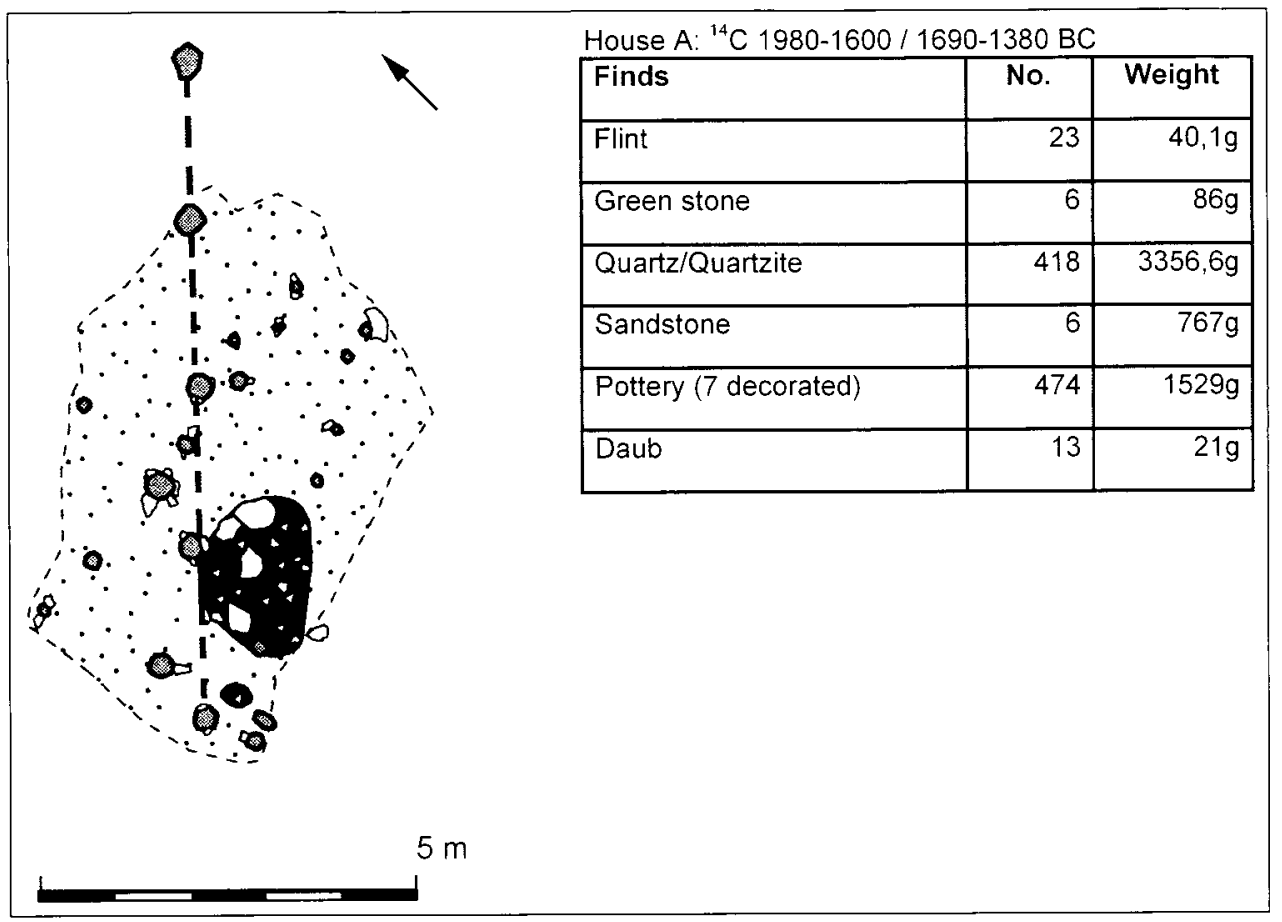

Fig. 8. Late Neolithic house excavated at Gröndal, Lunda Parish, Uppland. The floor was still visible as a colouration, and a hearth with soot and charred stones was also found. The hearth was ${ }^{14} \mathrm{C}$-dated to the Late Neolithic/Early Bronze Age, but a grain of wheat (Triticum sp.) found in a small cooking pit close to the hearth was dated to the Early Bronze Age. The suggested mid-section is shown with a broken line. (After Hamilton \& Runesson 2003: fig. 67c)

At Glasrutan 2 (Ullevi, Linköping), close to a previously excavated BAC double burial (Lindahl \& Gejvall 1955), a cultural layer that contained Neolithic artefacts and one BAC pottery sherd was found overlaying a small two-aisled house. The house was ${ }^{14} \mathrm{C}$-dated to the end of the Middle Neolithic B. Two more houses of a similar construction were found close by, but neither contained a notable amount of finds, or any organic material that could be dated (Biwall et al. 1997:288, fig. 7:27). Again we are faced with possible BAC houses - or Late Neolithic houses but with no way of making sure.

The difficulty of dating houses convincingly when we have little or no material from them can be exemplified by the 1998 excavation of SU 21, Dagstorp Parish, Scania, which I myself took part in. The site at SU 21 contained remains primarily from the Neolithic and Late Iron Age, but also the Late Bronze Age/Early Iron Age (Artursson et al. 2003; Lagergren-Olsson \& Linderoth 2000). In the eastern part of the site four two-aisled houses, $13-15 \mathrm{~m}$ long and 6-7 $\mathrm{m}$ wide, were identified, mainly in a W-E or NW-SE orientation and with similar construction details (fig. 10). The houses themselves contained very little material, apart from a few sherds of undecorated pottery and knapped flint. At one house (71) three 


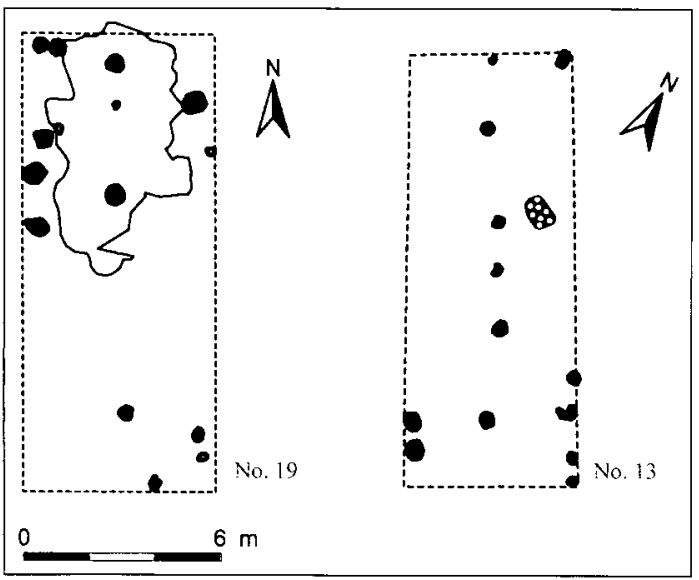

Fig. 9. Two-aisled houses found at Vrå, Knivsta Parish, Uppland. House 19 had a floor. layer of clay in the northern half, and house 13 had a cooking pit close to the centre. The site had remains from the late Middle Neolithic to the Early Iron Age, but no artefacts were recovered from these houses, nor any dated material. (After Göthberg et al. 2002: figs. $52,56)$

sherds of MN A-pottery were identified. At the site were also found three shallow and irregular cultural layers that contained large quantities of richly decorated $\mathrm{MN}$ A-pottery, knapped flint and flint tools. As can be seen in figure 10, three of the houses were found in connection to these layers, which led the excavators to interpret them as contemporaneous. Unfortunately no dates can verify this, since resin from house 71 was dated to $45904360 \mathrm{BC}$, charcoal from house 72 was dated to $7250-6770 \mathrm{BC}$, and no dates at all were obtained from house 74 (Artursson et al. 2003: 93, 95).

No cultural layer was found at house 70 , but altogether about $120 \mathrm{~g}$ of undecorated pottery, $350 \mathrm{~g}$ of knapped flint, $5 \mathrm{~g}$ of burned bone, and a few flint tools of general Neolithic types were found inside the house, as well as postholes (Artursson et al. 2003: 89ff). However, one sherd was considered by the excavators

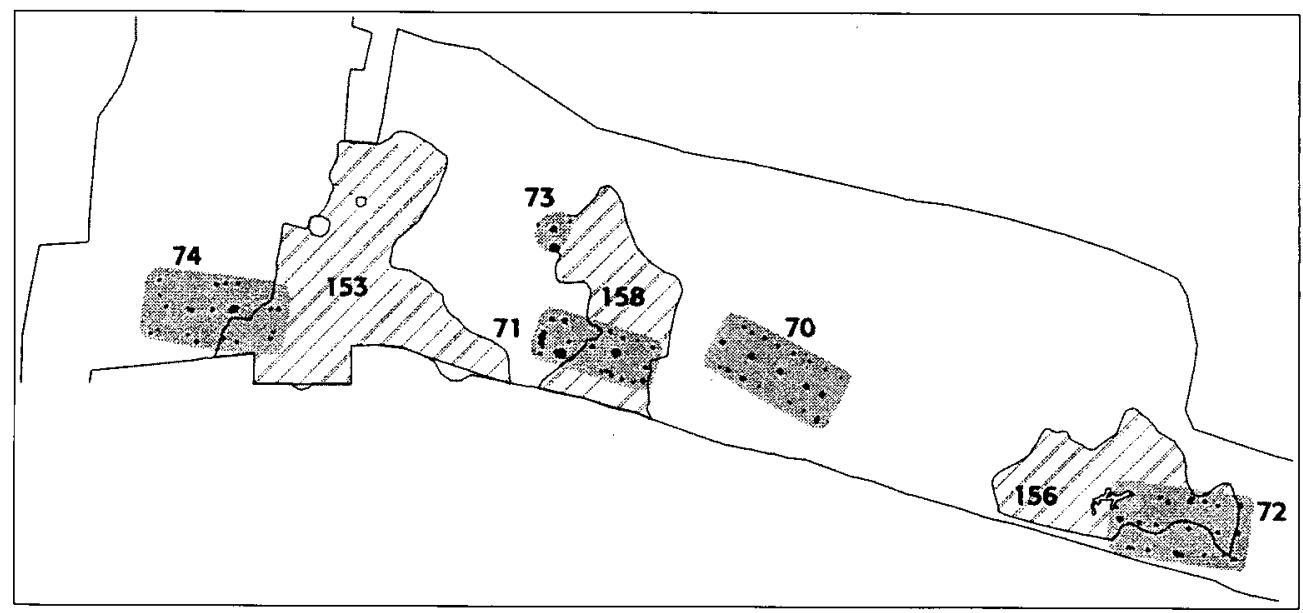

Fig. 10. Dagstorp (SU 21), Scania-eastern half of the site. The features and houses shown are those that have been interpreted as Neolithic by the excavators. Four two-aisled houses, one hut, and three coloured cultural layers with flint and pottery belonging to the TRB of the Middle Neolithic A. Only house 70 had ${ }^{14} \mathrm{C}$ dates that indicated the Neolithic-Early Neolithic and Middle Neolithic B respectively. The ${ }^{14} \mathrm{C}$-dates from houses 71 and 72 indicate the Mesolithic: house 74 was not ${ }^{14} \mathrm{C}$-dated. (After Lagergren-Olsson \& Linderoth 2000: fig. 4; Artursson et al. 2003: fig. 24) 
to resemble BAC pottery ware, which is often thinner and has little or no visible temper. It is therefore interesting that a hazelnut found in one of the roof-bearing postholes was ${ }^{14} \mathrm{C}$-dated to $2570-2320 \mathrm{BC}$. To complicate matters, a hazelnut shell found in one of the postholes from the wall was dated to the Early Neolithic (ibid: 91). Since house 70 was the best preserved of the houses, the excavators were inclined to believe the MN B dating more than the Early Neolithic, especially when combined with the possible BAC pottery sherd. However, the material was not deemed conclusive enough for such an interpretation.

The excavators are faced with several problems when interpreting the settlement remains at Dagstorp SU 21, and their conclusions are by no means beyond challenge, which they themselves are aware of. They solve this by full disclosure of the finds and features as well as all the dates - even those that do not confirm their interpretation - explaining on what grounds they draw their conclusions. By doing so, they are helping other archaeologists to follow their reasoning and form their own opinions, leaving the door open for future confirmation or reinterpretation in the light of new finds.

The TRB culture of the Middle Neolithic A apparently had a cultural practice which resulted in the formation of cultural layers with plenty of richly decorated vessels, flint tools and flint flakes. They are therefore fairly easy to discover and excavate, something which present-day archaeologists certainly appreciate. Apart from the Dagstorp site, similar features have been found at Svågertorp $8 \mathrm{~A}$ and Elinelund $2 \mathrm{~B}$, for example. What is interesting about these two sites is that they also contained remains from the Middle Neolithic B and Late Neolithic. At Svågertorp the longhouse mentioned above was found (fig. 7), and a ${ }^{14} \mathrm{C}$-analysis and a few sherds of LN pottery dated it to the Late Neolithic (Rosberg \& Lindhé 2001: 26ff). However, the richest remains from the site date to the MN A and were found in a small cultural layer close to the house (ibid: $31 \mathrm{ff}$ ) - compare this to Dagstorp above. If the seven sherds of LN pottery had not been preserved and the house not dated, this could easily have led to it being interpreted as a TRBhouse based on the finds from the layer.

Elinelund $2 \mathrm{~B}$ contained a very rich $\mathrm{MN}$ A cultural layer, and the creation of it is probably connected to what was interpreted as a small cult house, where parts of a human skull were also found (Sarnäs \& Nord Paulsson 2001:104ff). Close by were three houses that were partially overlapping - one dated to the $\mathrm{MN} \mathrm{B}$, two to the Late Neolithic (fig. 11). However, there were no notable finds from either of these periods: the MN B house contained $26 \mathrm{~g}$ of undecorated pottery and 24 flint flakes, and the two LN houses contained a little more flint but even less pottery (ibid: 126ff). Again, this highlights the danger in dating a house solely on the finds found in features outside it. This is especially true if one automatically chooses the features with the largest quantity of finds, since varying habits in different periods resulted in remains that may be more resilient to taphonomic processes - such as depositing large quantities of pottery, as was common in both the Middle Neolithic TRB and Pitted Ware culture. In contrast, it 
was not a common habit in the Late Neolithic or Early Bronze Age, and obviously not in the Battle Axe culture. Yet we seem to have no problem assuming there were Late Neolithic and Early Bronze Age settlements, even when houses are virtually empty, or indeed absent. We must seriously ask ourselves why we demand a greater amount of material evidence from the Battle Axe culture than from later periods.

\section{PATTERNS AND EXCEPTIONS IN CORDED WARE CULTURE SETTLEMENTS}

While local context is always important, it should not be forgotten that similar material culture and burial customs as those found in Sweden during the Middle Neolithic B, exist over a large area of the European continent. I would therefore like to widen our perspective to Europe, since the Swedish Battle Axe culture is but a local version of the greater Corded Ware culture complex, present in most of Northern and Eastern Europe at this time. I have two reasons for this. The first is to emphasise the fact that to view the BAC as simply a form of burial custom would imply that most of Northern Europe is little more than a huge cemetery at this time, devoid of human settlement. The fact is, and this is my second point, the Corded Ware culture (CWC) is quite infamous for its lack of clear and manifest settlements in most regions (BeneV 1997; Ebbesen 2006:147; Kempisty 1978:35ff; Milisauskas 2002:255ff; Turek 1997).

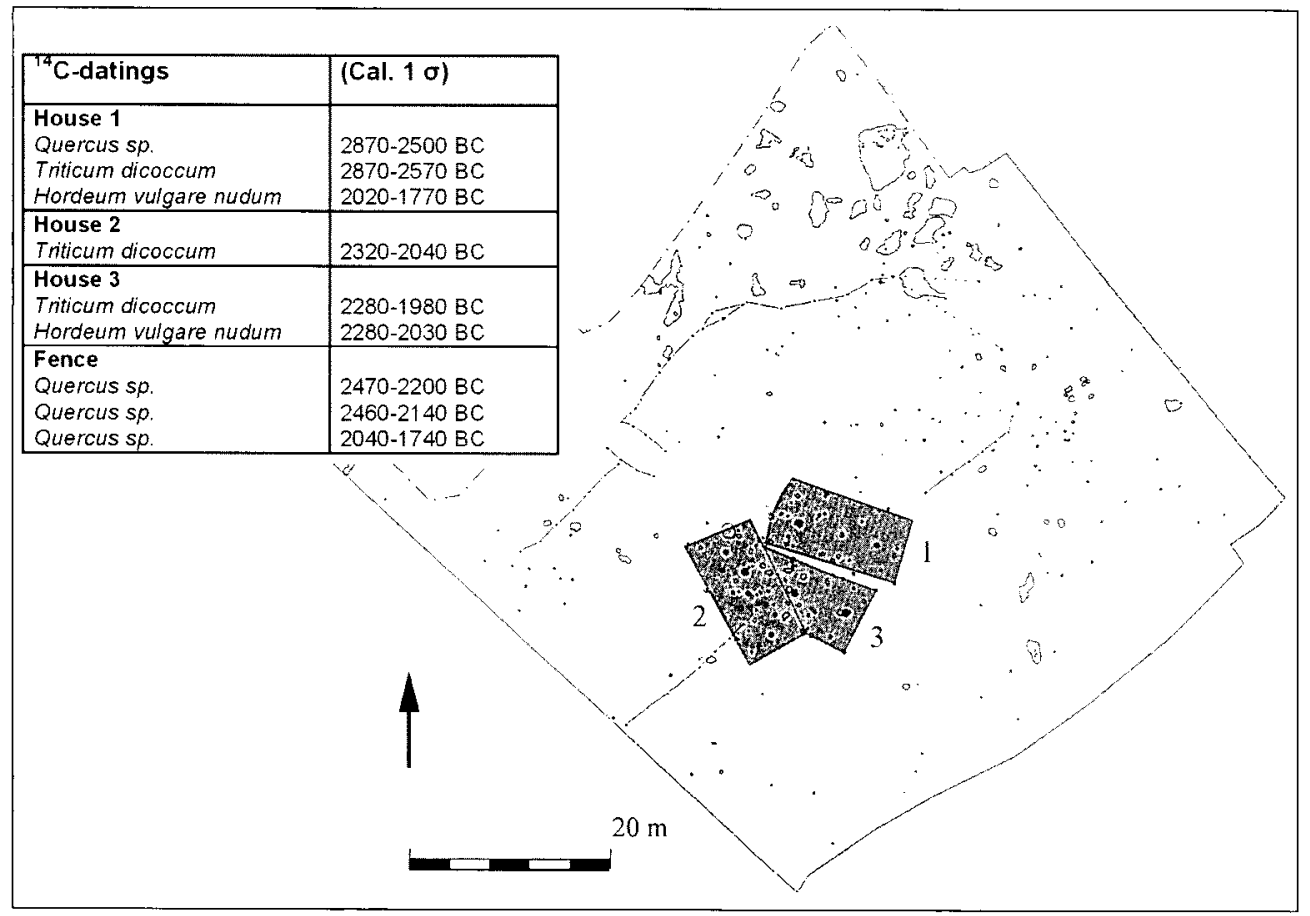

Fig. II. Three two-aisled houses found at Elinelund $2 B$, Malmö. Scania. They are partly overlapping each other; and the dates range from the Middle Neolithic $B$ to the Late Neolithic. There was also a fence structure dated to the Late Neolithic. (After Sarnäs \& Nord Paulsson 2001: fig. 121) 
There are, of course, some sites that have been interpreted as settlements, but most of them lack definable house structures. This absence is all the more apparent since the culture that most commonly precedes the CWC - the late TRB - is noted for its large settlement conglomerations (Milisauskas 2002:216ff; Müller 2003; Sherratt 1994:189, 192). All over the northern European continent, the CWC seems to practice an alternative form of settlement: mostly single houses on light soils on ridges, sometimes close to rivers and other bodies of water, though not immediately by the shore (Damm 1991:83; Edgren \& Törnblom 1998:87; Hogestijn 1992; Kriiska 2000; Sartes 1994; Turek 1997:236; Wlodarczac 2000:503).

There are exceptions to these elusive settlements that reveal some important archaeological lessons. Two areas have an abundance of rich settlement sites: Switzerland and Finland. The former has such sites because houses here were built on poles in lakes, where the water has preserved the structures to such a degree that they can be dated by dendrochronology (Wolf 1997). Finland is the most interesting exception, though, since there are several sites with large quantities of CWC pottery, in contrast to circumstances in other regions (Kritz 1989; Nielsen 1997). The sites are situated on slopes where sandy soil changed into clay soil, and close to running water but somewhat removed from the contemporary coastline - very much like the latter part of MN B in Sweden (Edgren 1970; Siiriäinen 1981:24).

So why are they so rich in finds when most other CWC settlements are not? The answer lies not in what the people of the Finnish Corded Ware culture did, but rather in what succeeding groups did. At the start of the Late Neolithic, these types of localities were abandoned, as the Kiukais settlements in SW Finland were again concentrated to the coast (Edgren \& Törnblom 1998; Sartes 1994; Siiriäinen 1981:25). Most CWC sites were discovered thanks to the fact that they were used for cultivation in historical times. While CWC sites are often found on top of older settlements, there are generally no remains from later periods until the Late Bronze Age/Iron Age - if any re-settlement took place at all (Edgren 1970; Edgren \& Törnblom 1998:87; Purhonen \& Ruonavaara 1994). In other words, the material was not immediately subjected to centuries of continued settlement, rebuilding and destruction.

\section{SETTLEMENT CONTINUITY AND ITS CONSEQUENCES}

This break in settlements is not the case in most of the other parts of the CWC area. Both in Sweden and many other countries, there is a notable continuity between especially the later CWC settlement sites and the Late Neolithic and Bronze Age; late types of CWC artefacts are often found at settlements from these younger periods. The material remains are not of a great quantity to begin with, and have then been additionally fragmented and destroyed by the continued settlements. Compared to Finland, there was less of a buffer period in which the remains could be covered up by natural processes. There are even some examples 
of LN houses that have probably been rebuilt on top of BAC houses in Sweden.

One such house was excavated at Paragrafen (Stång), Linköping. Here a twoaisled longhouse, $17 \times 7 \mathrm{~m}$, was found and ${ }^{14} \mathrm{C}$-dated to c. $2130-1890 \mathrm{BC}$. However, an older line of wall posts could be seen, and several $\mathrm{BAC}$ finds were made close to this site (Biwall et al. 1997:fig. 7:30). It is suggested that an older BAC house could have been rebuilt in the LN (ibid: 290f). A more obvious example was excavated at Dagstorp 11 (SU 17), Scania, only $2 \mathrm{~km}$ from the abovementioned SU 21. At this site ten burials were found forming a line cemetery, nine of them belonging to the BAC and one to the LN (Andersson 2004:122ff). Some $25 \mathrm{~m}$ east of these graves a house was found, or rather two practically identical houses oriented NNW-SSE and superimposed on each other, but one was shifted $2 \mathrm{~m}$ to the north (fig. 12). Each house also seems to have been rebuilt at least once, bringing this to four phases of settlement (Artursson 2005:19; Artursson et al. 2003:84ff).

About $120 \mathrm{~m}$ north of the houses, a flint knapping site for the manufacture of thick-butted axes of the type used in the Middle Neolithic B was found (Andersson 2004:121). However, inside the house very little material was retrieved: $786 \mathrm{~g}$ of flint, $61 \mathrm{~g}$ of pottery (mainly undecorated), two round scrapers, a pair of flint cores, and two fragments of polished axes, of which one came from a hollowedged axe. In a cultural layer connected to the houses were remains from the

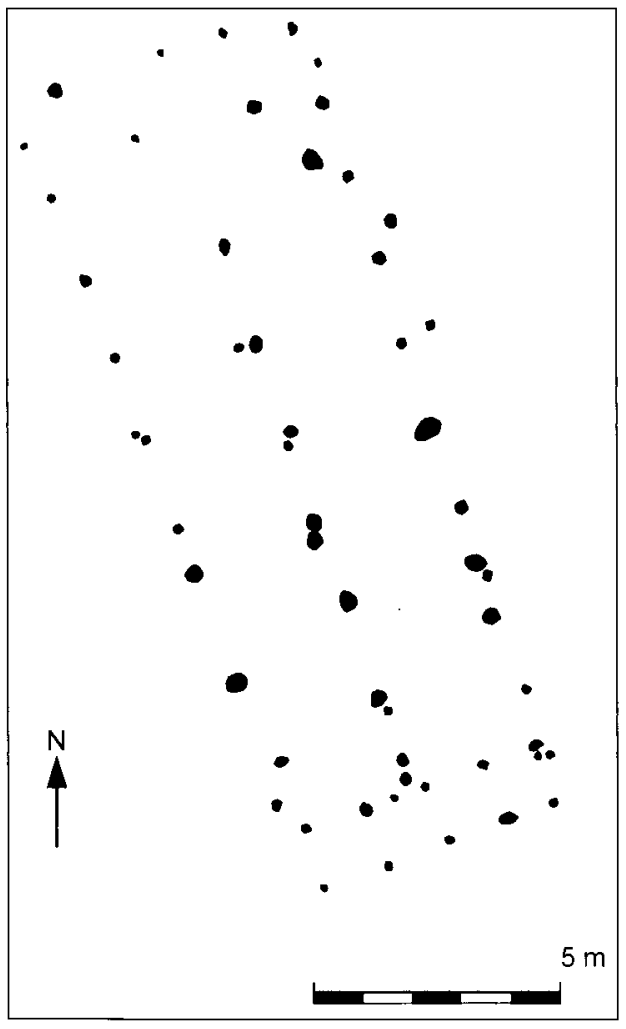

TRB, the BAC and the LN. Radiocarbon analyses of charcoal from two of the postholes yielded dates to $3020-2700$ $\mathrm{BC}$ and 2280-1980 BC respectively (Andersson 2004:119; Artursson et al. 2003:87). Taking into consideration the graves, the artefacts and the ${ }^{14} \mathrm{C}$-dates, I would say that at least one and probably more of the phases of the house belong to the $\mathrm{BAC}$, and the last to the $\mathrm{LN}$. This is not to say that there has been an uninterrupted settlement at this site. It is more likely that the social unit living here (i.e., an extended family) moved to alternate locations after a few

Fig. 12. Overlapping houses found at Dagstorp 11 (Dösjebro SU 17), Scania. At least two identical houses, but one shifted $2 \mathrm{~m}$ northwest. The postholes indicate that each house might also have been rebuilt. ${ }^{14} \mathrm{C}$-dated to the early Middle Neolithic $B$ and the Late Neolithic. Only $25 \mathrm{~m}$ west of the house a line cemetery was found, consisting of nine Battle Axe burials and one Late Neolithic burial. (After Artursson et al. 2003: fig. 20) 
generations when the fields had to lie fallow and the grazing needed to be renewed, only to return and rebuild a few generations further on. The posts could have been left standing to mark the location, both to help the rebuilding and to mark the territory as spoken for. The burials were also potential territory markers for a kinship group.

What helps in the interpretation of this site are the many burials close to it, graves that have no skeletal remains left, but burial gifts that belong to the BAC and ${ }^{14} \mathrm{C}$-dates to the $\mathrm{MN} \mathrm{B}$. In this instance the burials were visible through colourations and occasional stone packings, but there are many instances where the inhumation graves of the BAC are far more difficult to discern, and are recorded only through a favourable combination of luck and skill (e.g., Åstrand 2004).

\section{SOME EMERGING PATTERNS OF SPATIAL ORGANISATION IN THE NEOLITHIC}

Keeping Dagstorp 11 in mind, it is interesting to consider the settlement remains at Elinelund 2A (not to be confused with $2 \mathrm{~B}$ discussed above). At this site two longhouses were found and ${ }^{14} \mathrm{C}$-dated to the $\mathrm{MN} \mathrm{B} / \mathrm{LN}$ transition, as well as another two-aisled house that has not been dated. There were also 2-3 phases of dug wells close by, in which were found remains from these periods. Organic material from the bottom of one of the wells was ${ }^{14} \mathrm{C}$-dated to the MN B (Sarnäs \& Nord Paulsson 2001). While there are always difficulties knowing what exactly is dated in a well, this date is consistent with artefacts and material found at the site. As with Dagstorp 11 and Elinelund 2B, we have here another example of settlement continuity from the MN B into the LN. What is more, about $50 \mathrm{~m}$ south of the houses a small flint knapping site for the production of four-sided axes was found. The pattern of flint knapping sites somewhat removed from the immediate vicinity of the house, is repeated.

Of course, in eastern central Sweden the flint axes would be imported and not manufactured locally - here we would have to look for knapping sites for quartz and greenstone. In fact there is increasing evidence, in my opinion, that in the Middle Neolithic stone knapping - whether it was of flint, greenstone, or quartz - was often practiced at a distance from the main living quarters. The specialized flint-knapping sites of Hagestad 44, the evidence of ritualised flint axe manufacture at BAC palisades and at Kverrestad, and small, isolated, quartz knapping sites in central Sweden suggest this (Andersson 2004; Brink 2004; Holm 2004, Larsson 2000; Strömberg 1988). Settlement sites in Finland are also as notable for their poor quantities of knapped stone as their large quantities of pottery (Edgren \& Törnblom 1998:88).

I think it is important to note that large quantities of knapped greenstone or quartz are not even common at the Pitted Ware sites (Sittesta at Södertörn being one of the few exceptions), which are easier to discover thanks to their often substantial quantities of pottery. Nor are huts and houses always identified at these sites. Leaving aside the debate on whether these sites were true settlements, 
and only pointing out that house structures have been found (e.g., Artursson 1996), it is noteworthy that if the Pitted Ware people had manufactured and deposited vessels in the same manner as the Late Neolithic or early Bronze Age people, their sites would be no more obvious than these. Yet again we are faced with the problem of cultural practice and spatial organisation, not to mention the fact that many tools were probably made of organic material rather than stone. For all we know there could have been intensive manufacturing sites for bone tools at these settlements.

\section{BATTLE AXE POTTERY AT SETTLEMENTS}

In light of the above, it is clear that pottery is often our main criterion for ascribing a settlement to a specific Neolithic culture, since stone craft traditions are often continued over several periods, with the exception of certain prestige items such as flint daggers. For example, it is not always possible to ascertain whether flint refuse comes from the production of a thick-butted axe from the TRB, the BAC or even the LN; and pressure flake arrows were produced both in the LN and the early Bronze Age. But pottery is not always easily ascribed to a certain cultural tradition either, especially not heavily fragmented sherds from everyday vessels where only the rim was decorated. As we have seen above, most houses only yield a few nondescript and undecorated sherds of a general Neolithic type. BAC pottery is considered to be easier to identify thanks to the small rounded shape, grog-tempered ware and strict patterns. However, while pots of these types certainly occur at BAC settlements (e.g., Kabusa and Fågelbacken), there are other vessels belonging to this craft tradition that are not as characteristic, and this needs to be recognized.

Malmer sorted the BAC pottery mainly on the basis of their general decoration, not the shape of the vessel (Malmer 2002). This means that within each type there may be found both small, globular vessels as well as larger types. In figure 13 are shown the larger type vessels belonging to the BAC. The A- and E-type are decorated only at the rim, while the rest of the vessel is undecorated. They are also often tempered with crushed stone, solely or in addition to grog, which

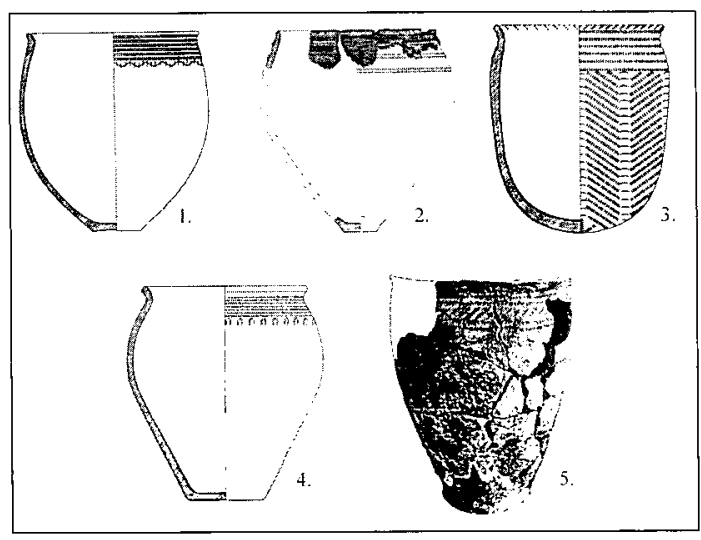
means their ware may not look significantly different from other Neolithic household pots. The Jvessels are occasionally more richly

Fig. 13. Large vessels fiom the Middle Neolithic $B$ and Late Neolithic. I: Type A (BAC)-cord decorated; 2: Type E (BAC)-dotted moulding; 3: Type $J(B A C)$ - comb, cord and/or whipped cord; 4: Type C (Late Neolithic) - cord decorated; 5: Late Neolithic vessel - whipped cord. Not to scale. (Malmer 1962; Strömberg 1975: fig. 27) 
decorated, with tooth stamp and whipped cord, but this is used on LN vessels as well (e.g., Strömberg 1975).

Many early BAC vessels are decorated with cord, which is also commonly used on Early Neolithic TRB pottery, and early BAC sites are often found at the same locations as the early TRB settlements (Malmer 1962). Sorting out which of the heavily fragmented cord-decorated sherds belong to which period can be a problem, especially in those cases where a lack of visible temper cannot always be used as a criterion to identify BAC pottery. It takes concentrated effort and knowledge of the material, not to mention time and money - often more difficult to come by - to sort out different phases at sites with mixed settlements. Archaeologists in the field need to recognize that Battle Axe pottery includes more types than small, fine-walled bowls.

\section{PROBLEMS AND POSSIBILITIES WITH THE ARCHAEOLOGICAL FIELD METHOD}

[D]espite numerous investigations of house layouts, there is a pronounced deficiency in smaller scale data concerning household relations in and around the long houses. The present day methods of excavating house structures usually means that systematic recovery of artefacts and their provenience are not given priority, whether because of resources, goals or an assumption that contexts will be disturbed and distorted. The house is a fundamental social arena(...) Investigation of this primary arena of the domestic sphere poses a challenge to the archaeology that investigates house structures in the field... (Prescott 2005:134)

Summing up, there are a number of houses that can be dated to the Middle Neolithic B, and some of these also have BAC material. If the BAC was only a burial custom, how do we explain these houses? If one would like to argue that they are still too few, or have too few finds to be interpreted as proper households, then this argument must be extended to include houses from the Late Neolithic and Bronze Age. The number of houses belonging to the MN B and LN north of Scania is about equal, and the quantity of material found in these houses, both in South Sweden and Central Sweden, do not differ to any notable degree.

A cultural practice of restricted ceramic production and deposits at settlements, and stone manufacturing areas placed at a distance from the house, increases the difficulties for archaeologists to find and identify BAC settlements. If these sites had been abandoned for several centuries after the Middle Neolithic B, as is the case in Finland, there would have been time for nature to create at least some protective covering before re-settling. However, if people and animals keep living at the same spot, the old remains will be heavily fragmented and cleared away, and the ${ }^{14} \mathrm{C}$-dates we obtain from a house will most often reflect the latest phase of occupation. Taphonomy teaches us that the remains we retrieve are dependent on many factors, and in unfortunate cases cultural practice and succeeding human 
activities at a site can combine to make a period very difficult to study archaeologically. In those cases the choice of field method is exceptionally important.

$\mathrm{BAC}$ settlements are not in any way impossible to find, as the examples given above hopefully show. However, in order to deepen our understanding of settlement strategies and spatial organisation during all of prehistory and not just the Middle Neolithic B, we need to implement a flexible and reflective field method. We cannot rely solely on the finds preserved in pits and postholes, but must combine the use of the excavator machines with test pits and hand-dug areas when they are called for. Otherwise we will keep finding houses of which no more can be said than that they were probably built and occupied during some broadly defined era. Material remains retrieved from the soil above the features, whether this is forest or field, must be compared to the structures found below.

There has been some debate in the archaeological community about the usefulness of artefacts retrieved from the topsoil, especially in cultivated fields. Since the ploughing has destroyed any possible vertical stratigraphy, and possibly also moved the material horizontally, it has been argued that it is a waste of time and money to include it in the excavation. The discovery of the previously missed house structures meant that there was an understandable priority among archaeologists in the 1980s and "90s to concentrate on finding these, with the help of large-scale surveys by machines. However, several archaeologists in Europe and USA have tried to seriously test the extent to which settlement material is transported during ploughing, and also what sort of information might still be found in the topsoil as compared to the features found below. Many of these texts are extensively presented in a report by Arne Sjöström and Henrik Pihl (Sjöström \& Pihl 1993). There are several important points to be made from the studies:

1. Most settlement activities take place on the surface, and very few actually result in features dug into the ground. Only rarely do prehistoric settlements create thick, coloured, cultural layers (Haselgrove et al. 1985).

2. Large objects will often be cleared away and deposited in rubbish pits, whereas smaller objects may remain more in situ. The latter are extremely difficult to find by any other means than digging test pits and sifting the soil (Tingle 1987).

3. While ploughing is destructive, it does not generally move artefacts horizontally to such a degree that the result is useless to archaeologists. The precise position of a single object cannot be trusted, but the general pattern may still be valid. However, no effort need be spent on the vertical stratigraphy in the plough zone (Ammerman 1985; Gren 1986; Odell and Cowan 1987).

4. Material remains and patterns should be studied in relation to features and structures, and vice versa, in order to achieve a better understanding of a prehistoric site (Apel et al. 1995; Larsson 1997; Lekberg unpubl.; Sjöström \& Pihl 1993:13ff).

5. Stone Age sites are often only visible in the material remains found in the 
topsoil, with few clear features and structures below. They are therefore disadvantaged by excavation methods that do not take this material into consideration (Björhem \& Säfvestad 1993; Holm and Rieck 1992; Jacobsen 1984; Thrane 1978).

One important note is that, even in cases where material has been collected in the topsoil, it has seldom been registered and analysed systematically (Larsson 1997:23; Sjöström \& Pihl 1993:2). The material has not been related to the archacological context, nor published in a manner useful to other archaeologists. The reporting and publication of an excavation is just as important as the method employed. What we may find in the plough layer will be fragmented and mostly unimpressive in itself, because it is mainly the remains of everyday life. However, when treated as a spatial pattern and compared to structures revealed after removing the soil, it will have the potential to deepen our understanding of prehistoric sites significantly (e.g., Apel et al. 1995; Prescott 1995).

The small fragments of pottery, burnt bones and knapped quartz found at Fågelbacken were perhaps not very informative in themselves. But when the area was stripped by machine, they were found to be part of the floor of a house whose dating to the Battle Axe culture could then be established (see figs. 3, 4). A similar - but completely reversed - result was found at the Mesolithic site at Motala, where the distribution of artefacts and stone refuse marked the walls outside the houses. In this case the living space was meticulously cleaned out. Motala resulted not just in a settlement with dwellings, but also valuable insights into cultural practice and spatial organisation (Andersson \& Carlsson 2005).

It is because settlement remains are fragmented and unimpressive that we need to employ methods of pit digging and water sifting of the topsoil - it is the only way to retrieve the pottery fragments, stone refuse, and often minute osteological material so that spatial analyses can be made of houses and sites. This is not a method aimed at finding impressive artefacts for museum display, but rather a method aimed at creating a deeper understanding of past lives. At sites with many different periods present there are, of course, difficulties relating features and finds to postholes and structures. Pit digging and water sifting will not mean an end to all controversy. It will, however, create much needed added opportunities to understand the complex events and activities taking place at a site.

This article started with a discussion on the difficulty of finding houses before the introduction of the excavator machine. The discussion highlights two important points:

1. Field method is vital for the sort of material found and the theories constructed about past societies. 2. Excavator machines are an incredibly valuable addition to the archaeological field method. This text is in no way an attempt to remove these machines from the excavations - quite the opposite. However, I hope that I have been able to show that removing all the topsoil by machine without making a methodical study of the material in it will seriously disadvantage certain time 
periods. It will also seriously restrict our knowledge of the spatial organisation of all periods. There must be opportunity for a more flexible field method, where test pits, hand-dug areas and water sifting are used in addition to stripping large areas by machine. The latter method helps us find houses and larger structures, while the former will hopefully help us identify spatial patterns both on a small scale and a large, as well as offer better opportunities to date the remains we are investigating.

Finding a house should only be a starting point: Questions of internal and external spatial organisation, regional differences and temporal changes, etc. must be addressed. In order to provide these answers, we need to retrieve more material, and our field methods are therefore of paramount importance. The field method needs to be granted a more prominent place in the archaeological debate, because the revelations made in the field will always guide and challenge the interpretations made by researchers, just as theories may open new areas of discovery in the field. We can simply ponder what our theories on prehistoric society would be like today, if we had stopped excavating in 1979. 


\section{REFERENSER}

Ammerman, A. J. 1985. Plow-Zone Experiments in Calabria, Italy. Joumal of Field Archaeology 12:33-40.

Andersson, H., and T. Carlsson. 2005. "Ristat i rader - två dekorerade hornföremål från mesolitikum funna i Motala," in Fornvännen, vol. 2005, pp. 5-I1.

Andersson, M. 2004. Making place in the landscape. Early and Middle Neolithic societies in two west Scanian vallevs. Skånska spår - arkeologi längs Västkustbanan. Lund: RÄ̈.

Apel, J. E., Y. Bäckström, F. Hallgren, K. Knutsson, P. Lekberg, E. Olsson, M. Steineke, and L. Sundström. 1995. Fågelbacken och trattbägarsamhället. Tor 27:47-132.

Artursson, M. 1996. Bollbacken, en sen gropkeramisk boplats och ett gravfält från äldre järnålder: RÄ̈ 258, Tortuna sn, Västmanland. Upplands Väsby: Arkeologikonsult AB.

- 2005. Byggnadstradition och bebyggelsestruktur under senneolitikum och bronsålder. Supplement till Skånska spår - arkeologi längs Västkustbanan. Lund: RAÄ.

Artursson, M., T. Linderoth, M.-L. Nilsson, and M. Svensson. 2003. "Byggnadskultur i södra och mellersta Skandinavien," In: M. Svensson (Ed) I det neolitiska rummet, Skånska spår - arkeologi längs västkustbanan. pp. 40-171. Lund: RAÄ.

Aspeborg, H. 1997. "Anläggningsfrekvenser i tid och rum," In: (Ed) Boplatser i Uppsala och Västmanlands län del II. pp. 19-26. Uppsala: Riksantikvarieämbetet.

BeneV, J. 1997." New ideology versus taphonomy: a case study of Czech Corded Ware in an erosional landscape," In: P. Siemen (Ed) Early Corded Ware Culture. The A-Horizon-fiction or fact? International Symposium in Jutland 2nd-7th May 1994, Arkaeologiske Rapporter nr 2. pp. 23-29: Esbjerg Museum.

Bennett, A. 1985. Karleby och Gärtuna. Bebyggelse och gravar från bronsålder och järnålder i Östertälje socken Södermanland. Rapport UV 1984:29. Stockholm: Riksantikvarieämbetet.

Beskow-Sjöberg, M. 1977. "The Iron Age Settlements of the Skedemosse Area on Öland, Sweden,"In: U. E. Hagberg (Ed) The Archaeology of Skedemosse IV. Stockholm: Almqvist \& Wiksell Int.

Biwall, A., R. Hernek, B. Kihlstedt, M. Larsson, and I. Torstensdotter Åhlin. 1997. "Stenålderns hyddor och hus i Syd- och Mellansverige," In: M. Larsson and E. Olsson (Ed) Regionalt och interregionalt. Stenåldersundersökningar i Syd-och Mellansverige., Skrifter nr 23. pp. 265-300. Stockholm: Riksantikvarieämbetet.

Björhem, N., and U. Säfvestad. 1989. Fosie IV. Byggnadstradition och bosättningsmönster under senneolitikum. Malmöfynd 5. Malmö: Malmö museer.

- 1993. Fosie IV. Bebyggelsen under brons- och järnålder. Malmöfynd 6. Malmö: Malmö museer.

Borna-Ahlkvist, H., L. Lindgren-Hertz, and U. Stålbom. 1998. Pryssgården. Från stenålder till medeltid. Rapport UV Linköping 1998:13. Linköping: RÄ̈.

Brink, K. 2004. The palisade enclosure at Hyllie, SW Scania. Journal of Nordic Archaeological Science 14:35-44.

Carlsson, A. 1998. Tolkande arkeologi och svensk forntidshistoria. Stenåldem. Stockholm Studies in Archaeology, No 17. Stockholms universitet: Department of Archaeology.

Damm, C. B. 1991. Continuity and Change. An Analysis of Social and Material Patterns in the Danish Neolithic. Ph. D. Thesis. University of Cambridge: Deptartment of Archaeology.

Ebbesen, K. 2006. The Battle Are Period. Copenhagen: Attika.

Edgren, T. 1970. Studier över den snörkeramiska kulturens keramik i Finland. Vol. 72. Finska Fornminnesföreningens Tidskrift. Helsingfors.

Edgren, T, and L. Törnblom. 1998. Finlands Historia 1. Esbo: Schildts Förlags AB.

Eriksson, T. 1997. "Keramiken," In: H. Göthberg, S. Forenius, and L. Karlenby (Ed) I en liten Vrå av världen. Arkeologiska undersökningar Vrä, Knivsta sn. Uppland, UV Uppsala Rapport 1997:66. pp. 123-154. Uppsala: Riksantikvarieämbetet.

Gill, A. 2003. Stenålder i Mälardalen. Stockholm Studies in Archaeology 26. Department of Archaeology: Stockholm University.

Gren, L. 1986. "Att inventera stenåldersboplatser i åkermark - exempel frăn Varaslätten och Falbygden i Västergötland," in Arkeologi i Sverige, vol. 1984, pp. 51-64. 
Göthberg, H. 1995. " Huskronologi i Mälarområdet, på Gotland och Öland under sten-, brons- och järnålder," In: H. Göthberg, O. Kyhlberg, and A. Vinberg (Ed) Hus \& gård i det förurbana samhället - Rapport frïn ett sektorforskningsprojekt vid Riksantikvarieämbetet, Arkeologiska undersökningar, Skrifter nr 14. pp. 65-109. Stockholm: RÄ̈.

Göthberg, H., S. Forenius, and L. Karlenby. Editors. 1997. I en liten Viåav världen. Arkeologiska undersökningar Vrå, Knivsta sn, Uppland. UV Uppsala Rapport 1997:66. Uppsala: Riksantikvarieämbetet.

Göthberg, H., O. Kyhlberg, and A. Vinberg. Editors. 1995. Hus \& gård i det förurbana samhället Rapport från ett sektorforskningsprojekt vid Riksantikvarieämbetet. Arkeologiska undersökningar, Skrifter $n r$ 14. Stockholm: RAÄ.

Hallgren, F. 2000. "Lämningar från stridsyxekulturen på Fågelbacken, Hubbo sn, Västmanland," in Tor, vol. 1998-1999, pp. 5-33.

- unpubl. "Stridsyxeboplatsen," In: P. Lekberg (Ed) Fågelbacken, ett fornlämningskomplex $i$ östra Västmanland., Rapport nr 14. pp. 36-49. Upplands Väsby: Arkeologikonsult AB.

Hamilton, J., and H. Runeson. 2003." Gröndal," In: J. Anund (Ed) Landningsplats - forntiden. Arkeologiska fördjupningsstudier kring yngre stenålder, järnålder och historisk tid inom det område som tas $i$ anspr:åk för den tredje landningsbanan vid Arlanda flygplats, Arkeologiska undersökningar, Skrifter $\mathrm{Nr}$ 49. pp. 121-162. Stockholm: Riksantikvarieämbetet.

Haselgrove, C., M. Millett, and I. Smith. Editors. 1985. Archaeology from the ploughsoil. Studies in the collection and interpretation of field survey data: Sheffield University Press.

Hogestijn, J. W. H. 1992. Functional differences between some settlements of the Single Grave culture in the northwestern coastal area of the Netherlands. Praehistorica XIX:199-205.

Holm, J. 2004. "Neolitiska slagplatser för kvarts. Exemplen Högby och Säbylund," In: J. Holm (Ed) Neolitiska nedslag. Arkeologiska uppslag, Arkeologiska undersökningar. Skrifter No 59. pp. 67-88. Stockholm: Riksantikvarieämbetet.

Holm, J., and F. Rieck. 1992. Istidsjagere ved Jelssøerne. Hamburgkulturen i Danmark. Skrifter fra Museumsrådet for Sønderjyllands amt, 5. Haderslev.

Hyenstrand, $\AA$. 1973. "Ett romartida gravfält i Romfartuna.," in Västmamlands fornminnesförenings årsskrift, vol. 1973.

Jaanusson, H. 1981. Hallunda. A Study of Pottery fiom a Late Bronze Age Settlement in Central Sweden. Stockholm Studies 1. Stockholm: The Museum of National Antiquities.

Jacobsen, J.A. 1984. A contribution to the evaluation of archaeological field surveying. Journal of Danish Archaeologv 3:187-198.

Karlenby, L. 1994." The Bronze Age House in Central Sweden. An evaluation of two recent excavations," in Tor, vol. 1994.

Kempisty, A. 1978. The Corded Ware Culture in Light of New Straigraphic Evidence. Przeglad Archeologic:zny 26:5-41.

Kriiska, A. 2000. "Corded Ware Culture Sites in North-Eastern Estonia," In: L. Jaanits and V. Lang (Ed) De Temporibus Antiquissimis Ad Honorem Lembit Jaanits, Muinasaja teadus 8. pp. 59-79. Tallinn: Teaduste Akadeemia Kirjastus.

Kritz, A. 1989. "Keramikrika och keramikfattiga stridsyxeboplatser i Finland och Sverige - ett tolkningsproblem," In: (Ed) Mänsklighet genom Millennier. En vänbok till Ake Hyenstrand., pp. 141-145. Stockholm: Riksantikvarieämbetet.

Lagergren-Olsson, A., and T. Linderoth. 2000. De neolitiska boplatslämningama på plats SU21. UV Syd Rapport 2000:22. Lund: RÄ̈.

Larsson, L.-I. 1997. "Massfynd från förhistoriska boplatser," In: (Ed) Boplatser i Uppsala och Västmanlands län del II. pp. 19-26. Uppsala: Riksantikvarieämbetet.

Larsson, L. 1989. " Boplatser, bebyggelser och bygder. Stridsyxekulturen i södra Skåne,"In: L. Larsson (Ed) Stridsyxekultur i Sydskandinavien, Institute of Archaeology Report Series, No. 36. pp. 53-76. Lund: Lunds universitet.

-2000. The passage of axes: fire transformation of flint objects in the Neolithic of southern Sweden. Antiquity; 74:602-610. 
Larsson, T. B. 1993. Vistad. Kring en befäst gård i Östergötland och Östersjökontakter under yngre bronsålder. Studia Archaeologica Universitatis Umensis 4. Umeå: Department of Archaeology.

Lekberg, P. Editor, unpubl. Fågelbacken, ett fornlämningskomplex i östra Västmanland. Rapport nr 14. Upplands Väsby: Arkeologikonsult AB.

Lindahl, A., and N. G. Gejvall. 1955. "Dubbelgraven från stenåldern vid Bergsvägen i Linköping," in Östergötlands och Linköpings Stads Museum, Meddelande, vol. 1954-1955, pp. 5-34.

Malmer, M. P. 2002. The Neolithic of South Sweden. TRB, GRK and STR. Stockholm: The Royal Swedish Academy of Letters History and Antiquities.

Milisauskas, S. Editor. 2002. European Prehistory: A survey. Interdisciplinary Contributions to Archaeology. New Jersey: Kluwer Academic/Plenum Publishers.

Müller, J. 2003. " Economic Continuity and Political Discontinuity in Central Europe During the Third Millennium BC," In: J. Czebreszuk and M. Szmyt (Ed) The Northeast Frontier of Bell Beakers, BAR International Series 1155. pp. 3-10. Oxford.

Nielsen, S. 1997. "The Corded Ware Culture in Finland," In: P. Siemen (Ed) Early Corded Ware Culture. The A-Horizon-fiction or fact? International Symposium in Jutland 2nd-7th May 1994, Arkaeologiske Rapporter nr 2. pp. 169-171: Esbjerg Museum.

Nordqvist, B. 1997. "Gropkeramikerna - fanns de? Västsverige," In: M. Larsson and E. Olsson (Ed) Regionalt och interregionalt. Stenåldersundersökningar i Syd-och Mellansverige., Skrifter nr 23. pp. 152-168. Stockholm: Riksantikvarieämbetet.

Odell, G. H., and F. Cowan. 1987. Estimating Tillage Effects on Artifact Distributions. American Antiquity 52:456-484

Petré, B. 1984. "Indikationer på bebyggelsekontinuitet, samhällsstruktur och ekonomi i östra Mälarområdet under yngre bronsåldern," In: Å. Hyenstrand (Ed) Bronsåldersforskning - kring aktuella begrepp, Archaeological Reports No 17. pp. 52-60. Stockholm: Department of Archaeology.

Prescott, C. 1995. From Stone Age to Iron Age. A study from Sogn, western Norway. BAR International Series 603. Oxford.

- 2005. "Settlement and Economy in the Late Neolithic an Bronze Age of Southern Norway: Some points and Premises," In: M. Høgcstøl, L. Selsing, T. Løken, A. J. Nærøy, and L. Prøsch-Danielsen (Ed) Konstruksjonsspor og byggeshikk. Maskinell flateavdekking - metodikk, tolking og forvaltning, AmSVaria 43. pp. 127-136. Stavanger: Museum of Archaeology.

Purhonen, P., and L. Ruonavaara. 1994. "On subsistence economy at the prehistoric dwelling-site area of Jönsas in Vantaa, Southern Finland," In: P. Purhonen (Ed) Fenno-ugri et slavi 1992. Prehistoric economy and means of livelihood. pp. 88-97. Helsingfors: Museovirasto.

Rosberg, A., and E. Lindhé. 2001. Öresundsförbindelsen. Svågertorp 8A [Engl. summany]. Rapport nr 13. Malmö: Malmö Kulturmiljö.

Sarnäs, P., and J. Nord Paulsson. 2001. Öresundsförbindelsen. Skjutbanorna IB \& Elinelund 2A-B [Engl. summary]. Rapport nr 9. Malmö: Malmö Kulturmiljö.

Sartes, M. 1994." Subneolithic and Neolithic settlement systems in South-West Finland. Discussion on resource areas," In: P. Purhonen (Ed) Fenno-ugri et slavi 1992. Prehistoric economy and means of livelihood. pp. 105-114. Helsingfors: Museovirasto.

Sherratt, A. 1994. "The Transformation of Early Agrarian Europe: The Later Neolithic and Copper Ages 4500-2500 BC," In: B. Cunliffe (Ed) The Oxford Illustrated History of Prehistoric Europe. pp. 167201. Oxford: Oxford University Press.

Siiriäinen, A. 1981. "On the Cultural Ecology of the Finnish Stone Age," in Suomen Museo, vol. 1980, pp. $5-40$.

Sjöström, A., and H. Pihl. 1993. Arkeologi frain ytan. Delrapport inom projektet " Det dolda kulturlandskapet ": Malmö Kulturmiljö.

Stjernquist, B. 1969. " En boplats från äldre järnålder i Hötofta, sydvästra Skåne," in Fornvännen, vol. 1969 , pp. 161-179.

Streiffert, J. 2005. Gårdsstrukturer i Halland under bronsålder och äldre järnålder. GOTARC Series B, Gothenburg Archaeological Theses No 39. Gothenburg: Riksantikvarieämbetet. 
Strömberg, M. 1975. Studien zu einem Gräberfeld in Löderup. Jungneolithikum bis römische Kaiserzeit. Grabsitte - Kontinuität - Sozialstruktur. Acta Archaeologica Lundensia, Series in $8^{\circ}$, No 10. Lund: CWK Gleerup.

- 1988. "A Complex Hunting and production Area. Problems Associated with a Group of Neolithic Sites to the South of Hagestad," in MLUHM, vol. 1987-1988, pp. 53-80.

Säfvestad, U. 1995. "Husforskning i Sverige 1950 - 1994," In: H. Göthberg, O. Kyhlberg, and A. Vinberg (Ed) Hus \& gård i det förurbana samhället - Rapport från ett sektorforskningsprojekt vid Riksantikvarieämbetet, Arkeologiska undersökningar, Skrifter nr 14. pp. 11-22. Stockholm: RAÄ.

Tesch, S. 1993. Houses, Farmsteads, and Long-term Change. A Regional Study of Prehistoric Settlements in the Köpinge Area, in Scania. Southern Sweden. Uppsala University: Department of Archaeology.

Thrane, H. 1978. Nogle iaktagelser og problemer i forbindelse med Sydvestfynsundersøgelsen. Skrifter fra Historisk Institut, Odense 23.

Tingle, M. 1987. "Inferential limits and surface artefact scatters: the case of the Maddle Farm and Vale of White Horse fieldwalking survey," In: A. G. Brown and M. R. Edmonds (Ed) Lithic Analysis and Later British Prehistory. Some Problems and Approaches, British archaeological reports. British series, 162. pp. 87-99. Oxford.

Turek, J. 1997. "The first evidence of Bohemian Corded Ware settlements and the question of their economy," In: P. Siemen (Ed) Early Corded Ware Culture. The A-Horizon-fiction or fact? International Symposium in Jutland 2nd-7th May 1994, Arkaeologiske Rapporter nr 2. pp. 233-242: Esbjerg Museum.

Ullén, I. Editor. 2003. Bronsåldersboplatsen vid Apalle i Uppland. Arkeologi på väg - undersökningar för E18. UV Uppsala Rapport 1997:64. Uppsala: RÄ̈.

Widholm, D. 1984. "Forskning kring bosättningsformer i Skåne under yngre bronsålder: några möjliga material och metoder," In: Å. Hyenstrand (Ed) Bronsåldersforskning - kring aktuella begrepp, Archaeological Reports No 17. pp. 85-86. Stockholm: Department of Archaeology.

Wlodarczac, P. 2000. " Corded Ware Culture Barrows in Western Little Poland," In: S. Kadrow (Ed) $A$ Turning of Ages. Jubilee Book Dedicated to Professor Jan Machnik on His $70^{\text {th }}$ Anniversary. pp. 481506. Kraków: Institute of Archacology and Ethnology, Polish Academy of Sciences.

Wolf, C. 1997. "Der A-Horizont in der Schweiz: Historische Reakität oder archäologísche Konvention?," In: P. Siemen (Ed) Early Corded Ware Culture. The A-Horizon-fiction or fact? International Symposium in Jutland 2nd-7th May 1994, Arkaeologiske Rapporter nr 2. pp. 243-266: Esbjerg Museum.

Åstrand, J. 2004. Tretton långhus och en begrawning - arkeologi i kv Seglaren. Rapport 2004: 11. Växjö: Smålands Museum. 